DOI: $10.2478 / \mathrm{v} 10014-010-0012-2$

Agrovoc descriptors: fagopyrum esculentum,fagopyrum tataricum,buckwheat,flavonoids,phenolic acids, aromatic compounds,phenolic compounds, antioxidants,vegetables,proximate composition,alternative methods

Agris category code: F60, Q04

\title{
Evaluation of buckwheat sprouts as microgreens
}

\author{
Dagmar JANOVSKÁ ${ }^{1}$, Lenka ŠTOČKOVÁ ${ }^{1}$, Zdeněk STEHNO ${ }^{1}$
}

Received March 25, 2010; accepted June 7, 2010.

Delo je prispelo 25. marca 2010; sprejeto 7. junija 2010.

\begin{abstract}
Microgreens from common and tartary buckwheat genotypes were evaluated for total flavonoid content (rutin, quercetine and kaempferol separately), bound phenolic acids content, carotenoids and $\alpha$-tocopherol content and antioxidant activity. The results have shown that in common and tartary buckwheat microgreens antioxidant activity was found. High level of flavonoids, carotenoids, and $\alpha$-tocopherol was detected as well. Higher amount of flavonoids was found out in tartary buckwheat microgreens. No significant differences were detected between common and tartary buckwheat microgreens in content of phenolic acids. Microgreens of both common and tartary buckwheat represent potential nutritional sources for alternative vegetable in the Czech Republic.
\end{abstract}

Key words: buckwheat, microgreens, flavonoids, rutin, phenolic acids, carotenoids, antioxidant activity

\section{IZVLEČEK}

\section{PREHRANSKE LASTNOSTI MLADIH RASTLIN AJDE}

Vsebnost celokupnih flavonoidov (posebej rutina, kvercetina in kempferola), vezanih fenolnih kislin, karotenoidov, $\alpha$ tokoferola in antioksidantna aktivnost so bili raziskani pri mladih rastlinah navadne in tatarske ajde. Ugotovljena je antioksidativna aktivnost izvlečkov mladih rastlin navadne in tatarske ajde ter visoka vsebnost flavonoidov, karotenoidov in $\alpha$-tokoferola. Posebej visoka vsebnost flavonoidov je bila ugotovljena pri tatarski ajdi, medtem ko glede na vsebnost fenolnih snovi ni bilo razlike med mladimi rastlinami navadne in tatarske ajde. Mlade rastline tako navadne kot tatarske ajde so možen alternativni vir zelenjave v Češki republiki

Ključne besede: ajda, mlade rastline, flavonoidi, fenolne kisline, karotenoidi, antioksidativna aktivnost

\section{INTRODUCTION}

Antioxidants help organisms to deal with oxidative stress, caused by free radical damage. Free radicals are chemical elements, which contains one or more unpaired electrons due to which they are highly unstable and cause damage to other molecules by extracting electrons from them in order to attain stability (Ali et al., 2008). Some of these molecules can be physiologically useful, but they can also cause damage under certain circumstances. The most notorious among these damages being neurodegenerative conditions like Alzheimer's and Parkinson's disease. Other neurodegenerative diseases significantly associated with oxidative stress include multiple sclerosis, CreutzfeldtJacob disease, and meningoencephalitis (Darley-Usmar and Halliwell, 1996; Ali et al., 2008). Reparative processes of organism are not sufficient enough to eliminate all damages in organism caused by free radicals. One of the possibilities how protect organism against free radicals is supplement of antioxidants. The main sources of antioxidants in the human nutrition are fruits and vegetables (Traka and Mithen, 2009).

Microgreens are very specific type of vegetable. They are very similar to sprouts but grow several days longer making them larger leaved, and greener, they are the crop being grown hydroponically and organically. Microgreens are considered to be in the group of what are newly referred to as "functional foods" which are food products that possess particular health promoting or disease preventing properties that are additional to their normal nutritional values. Demand for these products is growing rapidly. Microgreens have been found to contain higher levels of concentrated active compounds than found in mature plants or seeds.

\footnotetext{
Department of Gene Bank, Crop Research Institute, Drnovská 507, 161 06, Prague 6-Ruzyně, Czech Republic, e-mail: janovska@vurv.cz
} 
Microgreens are filled with vitamins, minerals, and antioxidants (MicroGreensUSA, 2009; Brentlinger, 2007). Common microgreens are grown mainly from cabbage, beet, kale, kohlrabi, mizuna, mustard, radish, Swiss chard, and amaranth.

Common buckwheat is traditional crop in the Czech Republic territory. It is very important for low-input agricultural system where it is one of most often growing crops (Michalová, 2003). Tartary buckwheat is not traditional in the Czech Republic, but in the last few years, there has been a demand for this crop, mainly as a medicinal plant, because of its high content of rutin and other polyphenols and suitability for the production of nutraceutical products and functional foods (Michalová, 2000).

The aim of this study was to evaluate common and tartary buckwheat as microgreens and to compare flavonoids, carotenoids, and selected phenolic acids content.

\section{MATERIALS AND METHODS}

\section{Plant materials and growth conditions}

The common and tartary buckwheat genotypes were obtained from the buckwheat collection of the Czech Gene Bank, CRI and from Institute of Biotechnology, Shanxi University, Taiyuan, China. The passport data about the samples origin are listed in Table 1.

Table 1 Passport data about the buckwheat samples

\begin{tabular}{cclc}
\hline No. & ECN* & Name of variety & Origin \\
\hline \multicolumn{4}{c}{ common buckwheat (Fagopyrum esculentum) } \\
$\mathbf{1}$ & $01 Z 5000072$ & Sudtirol Nr. 3 & unknown \\
$\mathbf{2}$ & $01 Z 5000123$ & Kara-Dag & Ukraine \\
$\mathbf{3}$ & 0125000127 & Jana & Ukraine \\
\multicolumn{4}{c}{ tartary buckwheat (Fagopyrum tataricum) } \\
\hline $\mathbf{4}$ & 0125100001 & unnamed & Bhutan \\
$\mathbf{5}$ & 0125100010 & Lifago & Germany \\
& & Jianzui & China \\
$\mathbf{6}$ & & Liu & China \\
$\mathbf{7}$ & & Jiujing & China \\
$\mathbf{8}$ & &
\end{tabular}

*National accession number

Common and tartary buckwheat seeds were soaked with distilled water for $24 \mathrm{~h}$ and shaken frequently. After that time, seeds were rinsed by running distilled water. Then they were put into holes of germination equipment and grown hydroponically. Microgreens were grown at daylight for 10 days until the first true leaves appeared. Plants were washed every day by distilled water. After cultivation, all samples were frozen in $-25^{\circ} \mathrm{C}$ and then lyophilized and milled for later extraction.

\section{Determination of DPPH activity}

Free radical scavenging capacity was evaluated according to the previously reported procedure using the stable DPPH radical according to Şensoy et al. (2006).
This method measures radical scavenging capacity and results are expressed as gallic acid equivalents per $\mathrm{g}$ of dry matter (mg GAE.g ${ }^{-1} \mathrm{dm}$ ). Antioxidant activities were determined by reacting $1 \mathrm{~mL}$ of methanolic extract of grains with $100 \mu \mathrm{L} 200 \mu \mathrm{M}$ DPPH. Absorbance of the samples at $515 \mathrm{~nm}$ was measured after $4 \mathrm{~min}$ reaction at room temperature in dark.

\section{Determination of total flavonoids, bound phenolic acids and carotenoids}

Total flavonoids were analysed spectrophotometrically after 1 hour extraction in mixture methanol: $\mathrm{H}_{2} \mathrm{O}$ : acetic acid (100:100:2) using non-specific reaction with $\mathrm{AlCl}_{3}$ and expressed as equivalents of rutin according to Van Hung et al. (2008). Three flavonoids - rutin, quercetine, and kaempferol were analyzed by HPLC method with UV detection according to Kreft et al. (2006) slightly modified. Comparing of retention time in sample and analytical standard was used for compound identification. Flavonoids were quantified using external calibration.

Bound phenolic acids were determined using HPLC with UV detection after the alkaline hydrolyzation according to Kim et al. (2006). Selected cinnamic acid derivatives (caffeic, p-coumaric, and ferulic acid) and benzoic acid derivatives (vanillic and syringic) were monitored at 320 and $280 \mathrm{~nm}$, respectively. Carotenoids were extracted with water-saturated butanol according to Hidalgo et al. (2006) and chromatographic separation was performed on $\mathrm{C} 18$ stationary phase with mixture of methanol, acetonitrile, and dichloromethane as mobile phase and spectrophotometric detection using in house method. Identification and quantification of all compounds was performed using external analytical standards. 


\section{RESULTS AND DISCUSSION}

\section{DPPH activity}

The DPPH activity (Fig. 1) depended on species and genotypes. Microgreens of both species possessed higher antioxidant activity than seeds. Microgreens of tartary buckwheat showed higher antioxidant activity than those of common buckwheat, contrary to Kim et al. (2008); they published similar results of antioxidant activity in common and tartary buckwheat sprouts grown for 10 days. Only common buckwheat genotype 'Sudtirol 3' had higher activity than genotype '01Z5100001' of tartary buckwheat. The tartary buckwheat varieties 'Jianzui' and 'Liu' originated in China showed the highest antioxidant activity.

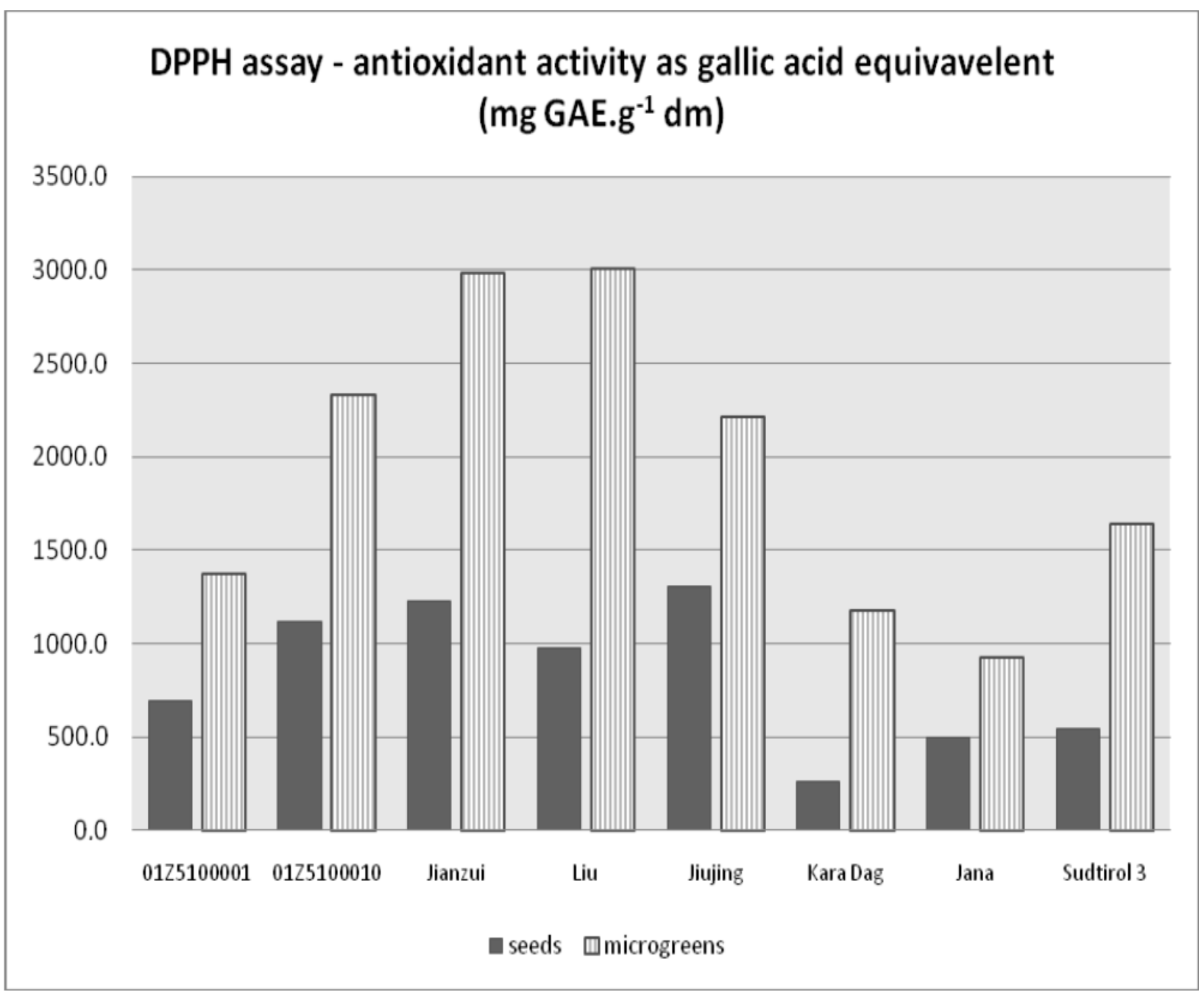

Fig. 1. DPPH assay of common and tartary buckwheat microgreens

Total flavonoids, phenolic acids and carotenoids

The quantities of phenolics such as flavonoids (including rutin, kaemferol, and quercetine), and phenolic acids (such as cinnamic acid derivatives caffeic, p-coumaric and ferulic acid and benzoic acid derivatives vanillic and syringic) and $\alpha$-tocopherol in microgreens from common and tartary buckwheat are shown in Fig. 2 and Fig. 3 respectively. The higher content of flavonoids was in tartary buckwheat microgreens. It corresponds with results of many authors; they published comparison of flavonoids content in seeds of tartary and common buckwheat (Fabjan et al., 2003; Kim et al., 2008). The main flavonoid in common and tartary buckwheat is rutin as published Liu et al. (2008). . Its higher content was detected in tartary buckwheat microgreens, which corresponded with Kim et al. (2008) who determined higher rutin content in tartary buckwheat sprouts. 


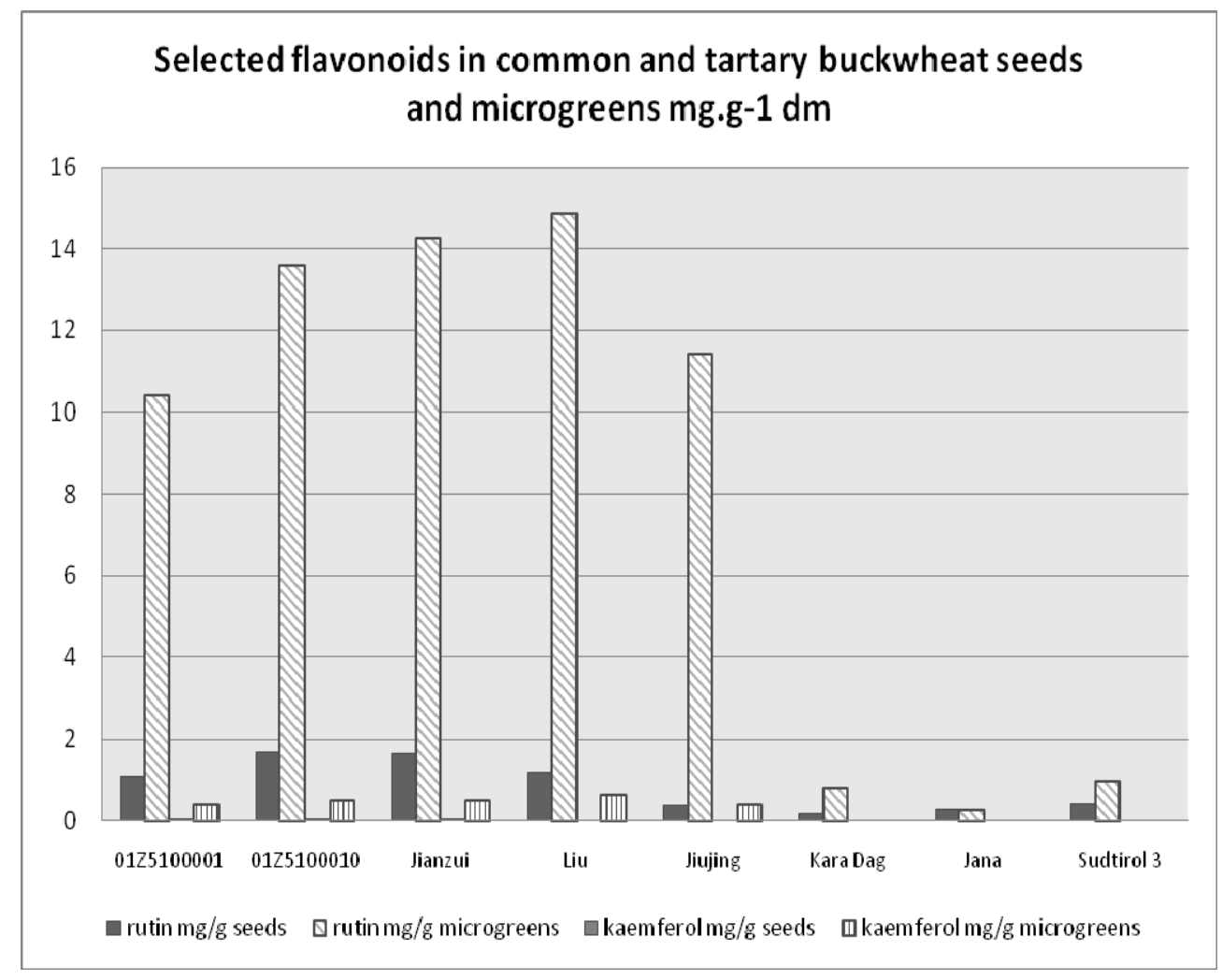

Fig. 2. Flavonoids in common and tartary buckwheat seeds and microgreens

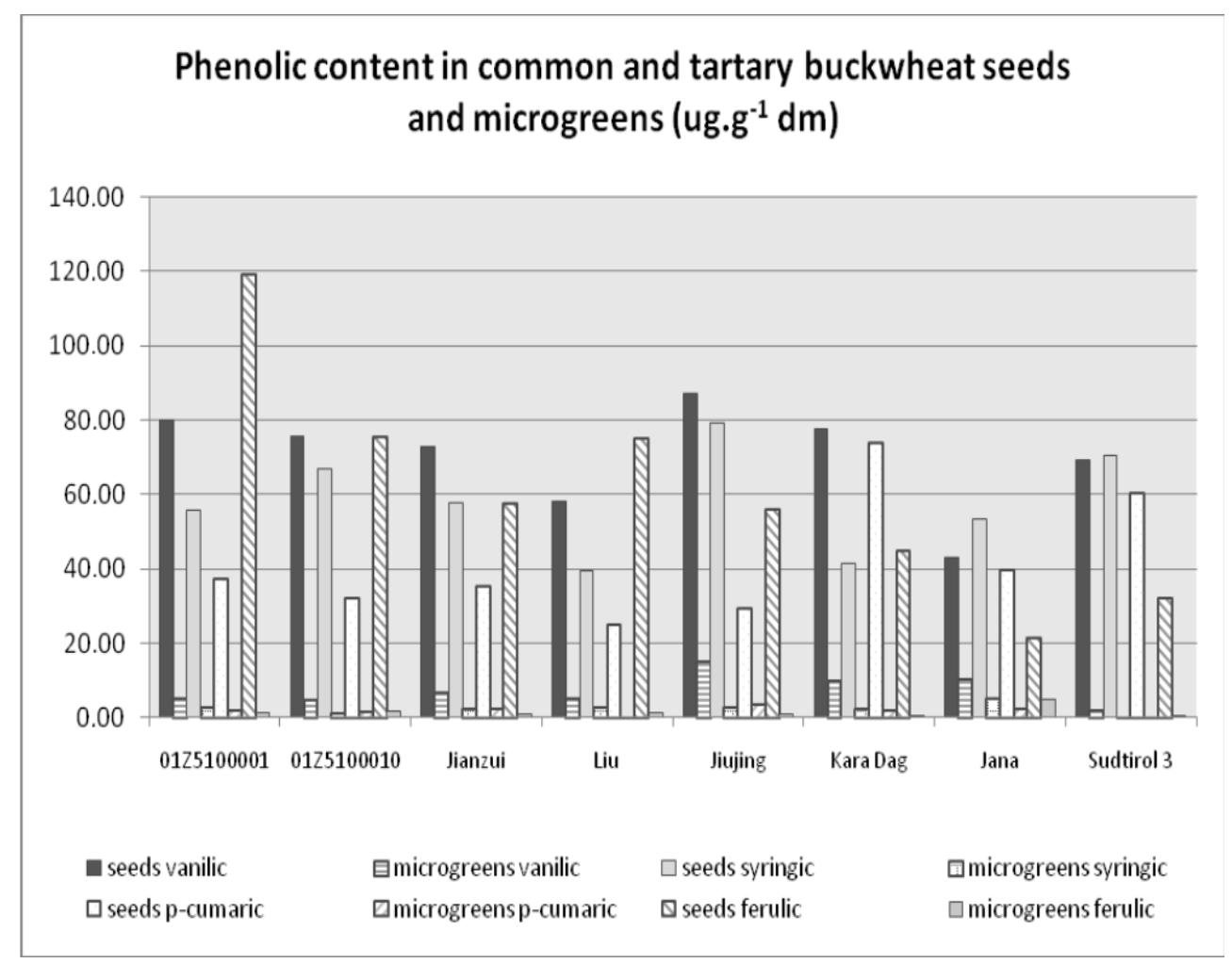

Fig. 3. Selected phenolic acids in common and tartary buckwheat seeds and microgreens 


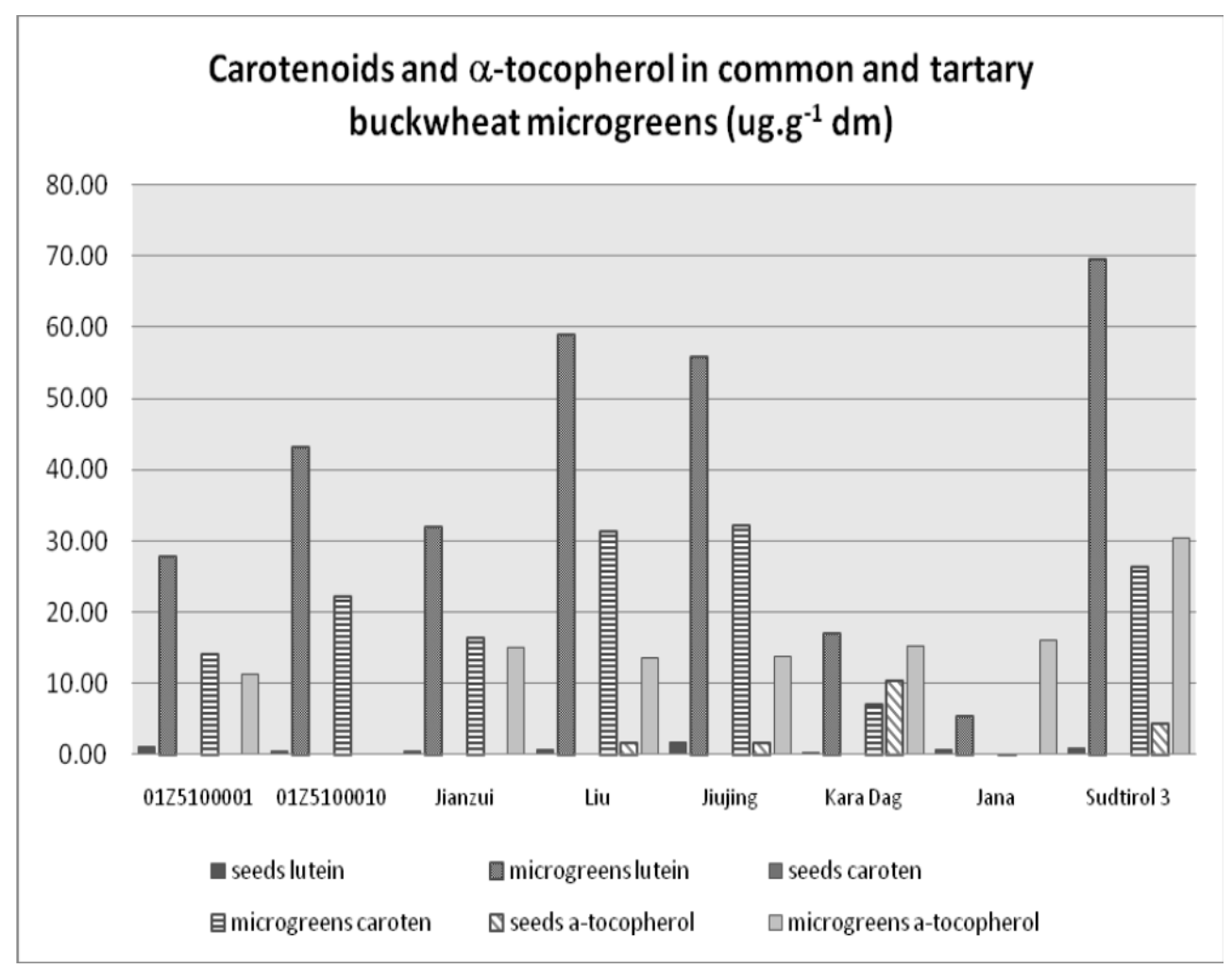

Fig.4. Selected carotenoids and $\alpha$-tocopherol in common and tartary buckwheat seeds and microgreens

No significant differences were detected in content of phenolic acids between common and tartary genotypes. On the other hand, the differences between seeds and microgreens in phenolic acids content were statistically significant. Generally, the amount of phenolic acids was higher in seeds than in microgreens of both species. Similar results published Alvarez-Jubete et al. (2010) in common buckwheat seeds and sprouts. In case of vanillic acid in microgreens, the highest amount was detected in tartary buckwheat genotype 'Jiujing' and the second highest level in common buckwheat variety 'Jana'. The caffeic acid was determined only in common buckwheat genotype 'Sudtirol 3'. Contrary to phenolic acids content, there was higher content of carotenoids and $\alpha$-tocopherol in microgreens than in seeds of both species. Caroten was under quantification level in seeds, which was 0.3 ug. $^{-1} \mathrm{dm}$. . In microgreens of 'Jiujing' genotype, the caroten level was more than 100times higher than in seeds Very similar results were obtained in the case of lutein and $\alpha$-tocopherol content in all genotypes. The highest content of lutein and $\alpha$-tocopherol was determined in microgreens of genotype 'Sudtirol 3'.

\section{CONCLUSION}

Our results have shown that antioxidant activity was found both in common and tartary buckwheat microgreens. High levels of flavonoids, carotenoids, and $\alpha$-tocopherol were detected as well. Higher amount of flavonoids was detected in tartary buckwheat microgreens. No significant differences were detected between common and tartary buckwheat microgreens in content of phenolic acids. Microgreens of both common and tartary buckwheat represent potential nutritional sources of alternative vegetable in the Czech Republic.

\section{ACKNOWLEDGEMENTS}

This work was supported by the research project of the Czech Ministry of Agriculture QH92111. 


\section{REFERENCES}

Ali S.S., Kasoju N., Luthra A., Singh A., Sharanabasava H., Sahu A., Bora U. (2008). Indian medicinal herbs as sources of antioxidants. Food Research International. 41:1-15

Alvarez-Jubete L., Wijngaard H., Arendt E.K., Gallagher E. (2010): Polyphenol composition and in vitro antioxidant activity of amaranth, quinoa buckwheat, and wheat as affected by sprouting and baking. Food Chemistry. 119(2): 770-778

Brentlinger D.J. 2007. New trends in hydroponic crop production in the US.. Acta Hort. (ISHS) 742:31-33

Darley-Usmar, V. Halliwell B. (1996). Blood radicals reactive nitrogen species, reactive oxygen species, transition metal ions, and the vascular system. Pharmaceutical research. 13(5): 649-662

Fabjan N., Rode J., Kosir I. J., Wang Z. H., Zhang Z., Kreft I. (2003). Tartary buckwheat (Fagopyrum tataricum Gaertn.) as a source of dietary rutin and quercetrin. Journal of Agricultural and Food Chemistry, 51, 64526455 .

Hidalgo A., Brandolini A., Pompei C., Piscozzi R. (2006): Carotenoids and tocols in einkorn wheat (Tritium monococcum ssp. monococcum L.). J. Cereal Sci. 44: $182-193$

Kim K.-H., Tsao R., Yang R., Cui S. W. (2006): Phenolic acid profiles and antioxidant activities of wheat bran extract and the effect of hydrolysis condition. Food Chem. 95 $466-473$

Kim S.J., Zaidul I.S.M., Suzuki T, Mukasa Y., Hashimoto N., Takigawa S., Noda T., Matsuura-Endo C., Yamauchi H. (2008): Comparison of phenolic compositions between common and tartary buckwheat (Fagopyrum) sprouts. Food Chemistry. 110(4): 814-820
Kreft I., Fabjan N., Yasumoto K. (2006): Rutin content in buckwheat (Fagopyrum esculentum Moench) food materials and products. Food Chemistry 98, $508-512$

Liu C.L., Chen Y.S., Yang J.H., Chiang B.H. (2008): Antioxidant activity of tartary (Fagopyrum tataricum (L.)Gaertn.) and common (Fagopyrum esculentum Moench.) buckwheat sprouts. Journal of Agricultural and Food Chemistry. 56:173-78

Michalová A. (2000). Minor Cereals and Pseudocereals in Europe. IN: Maggioni, L. Report of a Network Coordinating Group on Minor Crops. First meeting, June 16, 1999, Türku, Finland. IPGRI, Rome, Italy. 2000 .

Michalová A. (2003). Buckwheat in the Czech and Slovak Republic. In: Ethnobotany of Buckwheat

Şensoy I., Rosen R. T., Ho Ch., Karwe M. V. (2006): Effect of processing on buckwheat next term phenolics and antioxidant activity. Food Chemistry 99:388-393

Traka M., Mithen R. F. (2009): Health Benefits of Dietary Plant Natural Products. In: A.E. Osbourn and V. Lanzotti (eds.), Plant-derived Natural Products Synthesis, Function, and Application. Springer-Verlag New York 2009

Van Hung P., Maeda T., Miyatake K. Morita (2008) Total phenolic compounds and antioxidant capacity of wheat graded flours by polishing method. Food Res. Int. 42: $185-190$

MicrogreensUSA (2009): published on URL < http://www.microgreensusa.com/> [cit.2009-7-27]. 